\title{
Factors of Voluntary Mergers of Municipalities: a case study of the Czech Republic
}

\author{
Karolína Musilová ${ }^{1}$ \\ Jan Heřmánek ${ }^{2}$
}

\begin{abstract}
Territorial fragmentation is considered as one of the most problematic characteristics of the Czech municipal system, however, there are no effective ways how to encourage small units to amalgamate. This paper focuses on cases of voluntary mergers that occured in 2002 and 2003, as the number of amalgamated units had no comparison in last 20 years. Through the analysis of documents, data from statistical office, press and interviews with actors we examine the aspect of those mergers such as main causes, process of the merger itself and actors involved. The analysis reveals the amalgamation was not a result of long-term process but more likely an ad hoc solution of problematic situation caused by administrative, economic and socio-demographic factors.

This paper was supported by PRVOUK Project No. 17 - Vědy o společnosti, politice a médiich ve výzvách doby [Sciences of Society, Politics, and Media under the Challenge of the Times], Charles University in Prague, Faculty of Social Sciences, Institute of Political Studies.
\end{abstract}

Keywords: voluntary amalgamation of municipalities; fragmentation; municipal structure; Czech Republic; territorial reforms.

\section{Introduction}

The issue of territorial consolidation of municipal structure is currently one of the strongest drivers of changes at the local level in European countries, as well as one of the important topics of political science (compare Baldersheim, Rose 2010; Swianiewicz 2010; Baldersheim, Illner, Wollmann 2003; Dafflon 2012). With the increasing number of tasks of executives at all levels in last decades, especially in the field of economic planning, it appeared small local units failed to manage all the objectives. Efforts to provide citizens with a wide range of

1 Mgr. Karolína Musilová (1989), Institute of Political Studies, Fakulty of Social Sciences, Charles University, U Kříže 8, 15800 Prague, email: karolina.musilova@fsv. cuni.cz

2 Mgr. Jan Heřmánek (1989), Institute of Political Studies, Fakulty of Social Sciences, Charles University, U Kř́̌že 8, 15800 Prague, email: hermanekjohn@gmail.com 
new services launched a period seeking to reform the municipal structure in favour of larger municipalities which would be able to fulfill these functions (Keating, 1995, p. 120). European governments initially looked at the problem of insufficient capacity of small villages purely in economic terms and reforms were adopted without the consultation with local authorities.

Even the Czech and Slovak Republics have experienced this period. In Czechoslovakia, the communist regime decided to follow the development in Western Europe and the number of municipalities between 1947-1989 fell by almost two thirds (Illner, 2010, p. 17). The mandatory amalgamation was replaced by the period of fragmentation, when the number of municipalities had grown in two years by almost two thousand, with the situation in the Czech Republic being worse than in neighbouring Slovakia (Kling, Nižňanský, Pilát 2002, p. 118). Although political representatives are aware of the problematic issues arising from such a fragmented structure, they have not yet taken any measures that would explicitly head for consolidation. Potentially motivational legislative determination of taxes for the smallest municipalities was not accompanied by any informational and methodological support. As the current legislation does not allow any directive amalgamation, voluntary mergers play the key role in consolidating municipal structure.

These cases are discussed in the following text. In addition to compliance with formal conditions imposed by the Act on Municipalities ${ }^{3}$, the merger means that the municipality totally gives up its independence and entrusts its management to a larger unit (Steiner, 2003, p. 554). The reasons for such an action may be different. For example, the executive of the village itself may come to the conclusion that the renunciation of sovereignty may be an advantage for the community in the long term. Further, there may be a problem with indebtedness (see Hornek 2014), inability to perform tasks effectively, lack of human capital to ensure the running of the municipality, or a simple demand to change induced by a general dissatisfaction with the status quo. In the Czech Republic, the total number of municipalities in 2002 and 2003 decreased by 9 without any intervention by the central government. The number itself is, in proportion to the total number of municipalities, insignificant since it represents less than $0.5 \%$ of the total number of units and is fully compensated by the creation of the new ones. Examining individual cases of amalgamation is still advisable for several reasons. First, the description of the merge process itself brings new findings

3 Law 128/2000 Coll., § 19, 1-6: Assemblies of the affected municipalities enter into an agreement to merge or connect, if there is not an application for holding a local referendum on this issue within 30 days from publication of this decision, then it becomes valid, otherwise it is subject to approval by local referendum on this matter. 
that may help to identify conditions that lead to it, and which may be useful in a possible reform, whose target group would be size-matching to investigated cases. Secondly, although the literature examining the small municipalities is rather broad (compare Illner 2006; Bubeníček 2010; Bernard, Ryšavý 2013, Swianiewicz 2003; Wollmann 2012), the issue of voluntary mergers is still rather unexplored. Thirdly, a major wave of mergers occurred in 2002 and 2003, which corresponds to the attempt of political representation to utilize the instruments of negative incentives by reforming the revenue sharing to the detriment of the smallest communities (Parliamentary print 435/0, 2000). Finally, it is then necessary to emphasize that 2003 was the last year, when there was more than a single case of a voluntary merger of a municipality.

The aim of the following text is to investigate the factors that accompany a voluntary decision of municipalities in the Czech Republic to give up their sovereignty, and answer such questions like what unites the mergers in 2002 and 2003, what were the reasons for the mentioned municipalities and what factors influenced their cases to the extent that the connection was successful? Following this, the text examines, which are the prerequisites for the voluntary amalgamation of municipalities in the Czech Republic and what is the effect of current legislation. The first hypothesis refers to a new legislative determination of taxes, which came into power in 2001 and affected the incomes of smallest municipalities in following years. Another hypothesis is that the voluntary amalgamation only occurs with the incentives and support of the centre.

\section{Methods and structure}

The paper first introduces the context of a voluntary amalgamation of municipalities in Europe and presents the possibilities offered in this regard by the legislative framework of the Czech Republic. The contextual part created for the purposes of this article is based on information of national statistical offices and research of relevant legislature. In terms of resources the paper is based on several main pillars. Those are, in addition to the traditional literature, the primary documents produced by the concerned councils, secondly, articles informing about the merger in the press. The third source consists of academic work (Durčáková 2008), which was elaborated at various universities and provides a comprehensive description of the process. All election results and information about the candidates come from the server Volby.cz operated by the Czech Statistical Office. In case of Zahořany a semi-structured interview with the former mayor was held in May 2014 as an additional source of data. 


\section{Amalgamation of municipalities across Europe}

At the outset, it is important to emphasize that a period of consolidation cannot be considered as a homogeneous phenomenon. The reform period can be split up into two phases, which are divided by blind spot of the ' $80 \mathrm{~s}$, in which the states focused more on functional changes and in terms of amalgamation, rather negative arguments were accentuated (Swianiewicz 2002, p. 6). The first stage may be bounded by the years 1950-1972 and it is characterized by centrally undertaken reforms. It took place in the states of north-western Europe (e.g. UK, Sweden, Denmark) but also in the states of the Eastern bloc. The second stage is begins in 1990 and continues to the present day. It is characterized by a different approach to dealing with fragmentation: the reforms are much more often at least partly built on a voluntary basis and local actors are involved in the process. (Dafflon, 2012, p. 194).

Historically, most of the mergers were made by the central government that changed the municipal boundaries by law and replaced original communities by newly created units. European Charter of Local Self-Government meant a milestone in this approach as it says in Article 5, "Changes in local authority boundaries shall not be made without prior consultation of the local communities concerned, possibly by means of a referendum where this is permitted by statute." (Council of Europe 1985). The important question is, how citizens and elected representatives of the municipalities participate in this process, and whether it is possible for a municipality to be forced to amalgamate against their will. The answer is very different and depends on the country, where such a change occurred as well as on the legal framework, which differs significantly around the Europe.

\section{Possibilities for participation of municipalities in the process of merging}

European countries can be divided into three groups. In the first group of states it is not possible for municipalities to decide on their future independently and any change of borders requires special legal rights, while the central government does not have to take the opinion of local government into consideration. These include Portugal, Belgium, Luxembourg and Bulgaria. In these countries, the citizens are fully dependent on the contacts between local elected representatives and political centre.

The second group includes countries in which the local government can comment on the new arrangement, but its opinion is not binding. However, no special legislation is required at any part of the process. This group is in terms 
of numbers the greatest: it includes e. g. Austria, Denmark, Norway, Sweden, Finland, Greece, Italy, Spain, the United Kingdom and Poland.

The last group consists of states, where any change of municipal boundaries requires an approval by a municipality itself. These include the Czech Republic, Slovakia, Switzerland and France. The list above does not include all European countries, which corresponds with the fact that the characteristic is not static and we cannot say that in some countries, municipalities are legally protected from a possible directive reform forever and there are only voluntary paths to their merger.

Conversely, if the central government decides to approve the directive merge reform, it will not be a problem for it to adjust the conditions to the form, which will allow putting it into practice. An example of such a conduct is a constitution in Hungary approved in 2012, which allows the central government to merge municipalities (OECD, 2014, p. 272).

\section{Approaches to amalgamation}

As indicated, currently two approaches can be generally distinguished, which control the amalgamation processes. The first approach can be described as a directive, because the shape of the new structure is an integral part of the centrally-agreed legislative reform and municipalities alone (despite the fact that they can have advisory vote) do not determine its future. The second approach is purely voluntary amalgamation of municipalities, which takes place without any interference of the central government and each case is the result of a sovereign decision of the community.

These two approaches are rather ideal types, among which an imaginary axis can be found, where most of the cases of mergers in European countries are placed. To determine the element of voluntariness it is crucial to determine the extent to which the municipality has the option to decide firstly whether to merge and, secondly, with whom they will merge (compare with: Blesse and Baskaran, 2014, p. 19; and Saarimaa and Tukiainen, 2013, p. 6). 
Table 1: Comparison of reform types according to an extent of participation

\begin{tabular}{|l|l|l|}
\hline Merger type & $\begin{array}{l}\text { The municipality deci- } \\
\text { des whether to merge }\end{array}$ & $\begin{array}{l}\text { The municipality } \\
\text { decides with whom to } \\
\text { merge }\end{array}$ \\
\hline Voluntary & yes & yes \\
\hline Quasi-voluntary & no & yes \\
\hline Directive & no & no \\
\hline
\end{tabular}

Source: authors

The table shows that in addition to a simple dichotomy voluntary - directive merger there is an existing group of cases in which municipalities get into a situation, where they may choose a partner, but it is predetermined that the process ends in merger sooner or later even without their cooperation. In the literature, this method is often mistakenly referred to as "voluntary". While there is obviously a difference between the process that affiliates municipalities to the other ones on the basis of a direct decision, and use the freedom to choose a partner, the type above should not be labelled as voluntary. It cannot ignore the fact, that the village is built in a hopeless situation where non-acting (i.e. when the municipality does not choose a partner.) may further worsen its situation. Therefore, we use the term quasi-voluntary. For at least a certain degree of voluntariness in the first stage of the process we, therefore, include those cases into a further examination.

Quasi-voluntary and voluntary merging processes are influenced by other factors. For example, municipalities are encouraged to amalgamate by a wide variety of different tools of financial or administrative nature, which are also applied in different time horizons and a varying number of phases. The following categorization divides and further specifies voluntary and quasi-voluntary amalgamation by combining the principles that have governed the process:

\section{Category 1: quasi-voluntary amalgamation with support}

States that set (or determined several times by various parameters) the target number of municipalities and reached this objective biphasic, meaning that the first voluntary phase was followed by a directive amalgamation of municipalities that missed the possibility to choose a partner. States in this category are e.g. Denmark, the Netherlands and the majority of German federal states. 


\section{Category 2: voluntary amalgamation with support}

States which have established a long-term approximate target number of municipalities, and the target size, and approach this goal by supporting the voluntary forms of consolidation. The group is further divided into the states in which it occurs:

a) On-going voluntary amalgamation with the support from the central government (e.g. Switzerland, Finland, Norway);

b) Merging with support was rated as unsuccessful and the directive reform has been implemented (e.g. Latvia, Greece).

Switzerland is often cited as an example of functioning voluntary mergers. Although the legislative settings in cantons are different, it combines sophisticated merger support. These tools include a detailed strategy developed at a cantonal level which is complemented by "instructions" for the municipality on how to calculate the costs and benefits of the merger and how to proceed the entire process. In addition, municipalities are also offered legal and administrative advice. Following a successful merger, the municipalities are then granted financial support (Lago-Peñas and Martinez-Vazquez, 2013, p. 215).

\section{Category 3: Voluntary amalgamation without support}

Countries whose governments for diverse reasons do not deal with a fragmentation issue (the level of fragmentation is in their eyes fair, a reform was made before 1990 , or any change driven by the central level would meet public rejection) or opt for a different solution such as inter-municipal cooperation. Regarding the legislative settings, e.g. France or the Czech Republic fall into this category although their municipalities merge very rarely.

\section{Municipal structure of the Czech Republic and assumption to mergers}

Regarding the structure of municipalities, the main legislative body is directly elected council, whose size varies from 5 to 55 . The executive powers are exerted by the mayor elected by the council and by the executive board (compulsory in municipalities with more than 10000 inhabitants). In terms of tasks, Czech municipalities exercise both self-governing and state delegated powers. According the extent of delegated powers, they are divided into 3 groups. Municipalities of the $1^{\text {st }}$ type exercise only basic powers, municipalities of the $2^{\text {nd }}$ and $3^{\text {rd }}$ type (i.e. municipalities with commissioned office and municipalities with 
extended powers) execute delegated powers ${ }^{4}$ also for units in their surroundings. This division is the outcome of the public administration reform in 2001, which sought to transfer tasks to units with larger capacity.

In the Czech Republic, the restoration of local government after 1989 meant a massive fragmentation wave that raised the number of municipalities by more than $50 \%$ during the $90 \mathrm{~s}$. The final stabilization occurred at the turn of the millennium, when the number of municipalities stood at 6,258, which ranks the Czech Republic among the countries with the most fragmented municipal systems in Europe (Balík, 2009, p.18-21).

Table 2: Number of municipalities in the Czech Republic after 1990

\begin{tabular}{lllllllllllll}
\hline Year & 1990 & 1991 & 1992 & 1993 & 1994 & 1995 & 1996 & 1997 & 1998 & 1999 & 2000 & 2001 \\
\hline $\begin{array}{l}\text { Number } \\
\text { of units }\end{array}$ & 4100 & 5768 & 6097 & 6196 & 6230 & 6232 & 6233 & 6234 & 6242 & 6244 & 6251 & 6258 \\
\hline 2002 & 2003 & 2004 & 2005 & 2006 & 2007 & 2008 & 2009 & 2010 & 2011 & 2012 & 2013 & 2014 \\
\hline 6254 & 6249 & 6249 & 6248 & 6248 & 6249 & 6249 & 6249 & 6250 & 6251 & 6251 & 6253 & 6253 \\
\hline
\end{tabular}

Source: data provided by Czech Statistical Office

The trend was first seen as a democratic expression of the free will of small municipalities, but since the second half of the 90 s, state officials have implemented several measures ${ }^{5}$ to prevent further fragmentation and possibly

4 Those responsibilities are e.g. welfare benefits and financial and social support for disadvantaged people in case of $2^{\text {nd }}$ type municipalities or maintaining register office, issuing identity cards, passports etc., registering road vehicles, deciding on some issues concerning public roads, managing crises situations and administering welfare programmes in case of $3^{\text {rd }}$ type units.

5 Illner (2010, p. 227-229) divides these measures into five groups: 1) Stopping the process of fragmentation by increasing the threshold of 1000 as the minimum number of inhabitants of the new unit, a need to approve the secession of the majority of the citizens, and entrusting the Regional Office with the final decision-making right. 2) Simplifying the requirements for voluntary mergers. 3) Implementation and support of inter-municipal cooperation. 4) Reform of local government, which transfers some of the delegated tasks to municipalities with larger capacity. 5) Preparation of a plan to create 
reverse this trend.

In practice, these steps meant that at the turn of the millennium, the trend stopped completely and in the coming years, there was even almost unnoticeable decline in the number of municipalities. As shown in Figure 1, even in times of a strong fragmentation process, some voluntary mergers occurred. Since 1990, there have been in total 31 amalgamated municipalities. The Figure 1 reveals that the mergers took place in two waves. The first wave which runs from 19921995 , is, according to the general opinion, made up of the cases in which newly separated municipalities are simply looking for a new partner and then again cease to exist. As reported by M. Illner (Vajdová et al. 2006a, p. 36), in 17 cases the era of their independence did not exceed a period of more than 6 years.

Figure 1: The number of municipalities defunct by merger

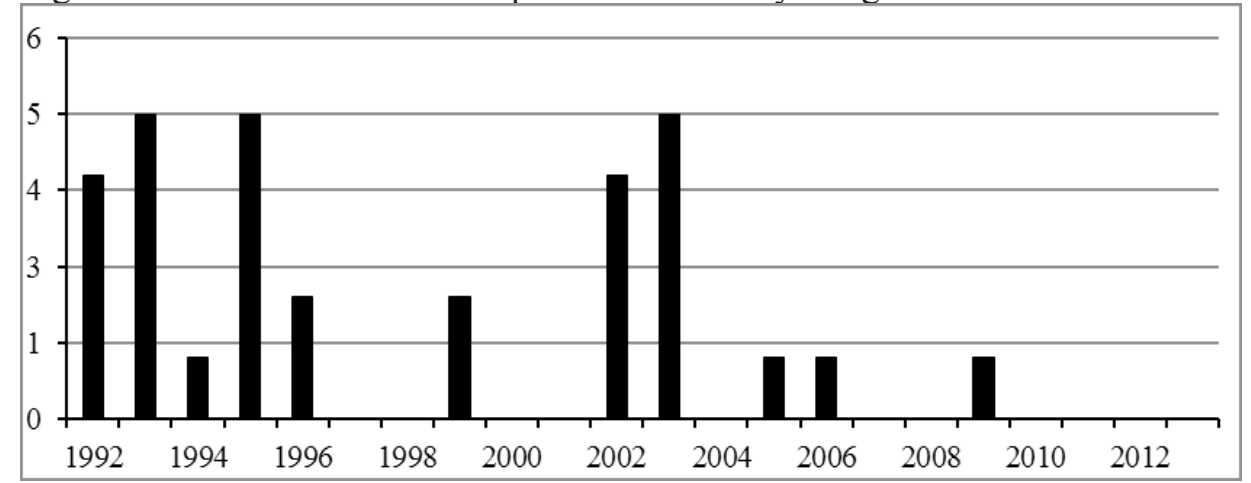

Source: data provided by Czech Statistical Office

The current position of the Czech Republic to the amalgamation of municipalities is already enshrined in the Constitution, whose Article 8 stipulates that "the autonomy of local governments is guaranteed," and Article 100, paragraph 1 says that "local governments are territorial communities of citizens who have the right to self-government." It also requires that the state could intervene into the municipal government only if it is necessary to protect the law and only in the manner prescribed by law (Article 101 para. 4).

Specific options for merging ${ }^{6}$ are governed by Act on Municipalities (no.

a community of municipalities, which however has not yet been adopted and does not appear among the priorities of political representation.

6 Act distinguishes merge and connection to another unit. A similar procedure applies when connecting; the property and liabilities of the former unit are transferred to a persisting one. For the purposes of this work, we will not undertake this terminological division. 
128/2000 Coll.) Municipalities may merge under the assumptions that together being physically adjacent, the merger was approved by each of the merging municipality and both units entered the agreement to merger $(\S 19$, Act No. 128/2000 Coll.) The approval of a simple majority of both councils is sufficient, but every citizen of the municipality has the right to submit a proposal for a local referendum, whose result is binding. The referendum will be held only in the municipality in which the proposal was submitted, it is, therefore, possible that one municipality was merged by the council and another one by the referendum.

\section{Voluntary merger of municipalities in 2002 and 2003: a case study Characteristics of the surveyed municipalities}

Characteristics of surveyed municipalities are presented in Table 3 . The previous experience with integration shows if the municipality was once part of a greater unit, and if so, which one. The only Malesice was not included in any consolidation process, Lhota conversely experienced the opposite, when Nová Ves joined Lhota between 1981 and 1990.

Another factor examined is the form of the political system and its possible influence on the later process of merging. For the purposes of this article we chose the plurality of the political system as main indicator based on the number of candidates entering the elections and the number of seats allocated. Plurality refers to a system where the number of candidates at least doubles the number of seats in the council. Non-plural system corresponds to a situation where the number of candidates is equal to the number of mandates. For cases where the number of candidates exceeds the number of seats, but does not reach twice that number, we choose the term semi-plural. Although the non-plurality does not necessarily mean dysfunctional political system $^{7}$, it often indicates a lack of interest in the candidacy. These systems often operate at the very limit of sustainability and independence of the village depends largely on whether at least one list of candidates runs for the elections. This issue is related to the size of the council, which is interesting especially in the context of population. It is evident that in some municipalities we surveyed, nearly one third of all citizens have to be involved.

7 As presented by Bubeníček (2010), the lack of candidates may be also a result of general satisfaction with current representatives. 
Table 3: Overview of examined cases

\begin{tabular}{|c|c|c|c|c|c|c|c|c|}
\hline \multirow{3}{*}{ Year } & \multirow{3}{*}{ Former unit } & \multirow{3}{*}{$\begin{array}{l}\text { Number of } \\
\text { inhabitants }\end{array}$} & \multirow{3}{*}{$\begin{array}{c}\text { Previous } \\
\text { experience } \\
\text { with } \\
\text { integration }\end{array}$} & \multirow{3}{*}{ Merged to } & \multicolumn{4}{|c|}{ Political system } \\
\hline & & & & & \multicolumn{2}{|c|}{$\begin{array}{l}\text { Plurality of political } \\
\text { system }\end{array}$} & \multicolumn{2}{|c|}{$\begin{array}{l}\text { Number of } \\
\text { councillors }\end{array}$} \\
\hline & & & & & 1994 & 1998 & 1994 & 1998 \\
\hline \multirow{4}{*}{2002} & Kalištẻ & 54 & $\begin{array}{l}\text { until } 1991 \\
\text { Śvihov }\end{array}$ & \multirow{3}{*}{ Śvihov } & Nonplural & Nonplural & 5 & 7 \\
\hline & Jino & 32 & $\begin{array}{l}\text { until } 1991 \\
\text { Śvihov }\end{array}$ & & Nonplural & Nonplural & 5 & 5 \\
\hline & Stropčice & 20 & $\begin{array}{l}\text { until } 1991 \\
\text { Śvihov }\end{array}$ & & Nonplural & Nonplural & 5 & 5 \\
\hline & Prosatin & 13 & $\begin{array}{l}\text { until } 1991 \\
\text { Blahoúov }\end{array}$ & $\begin{array}{l}\text { Kưuimská } \\
\text { Nová Ves }\end{array}$ & Nonplural & Nonplural & 5 & 5 \\
\hline \multirow{4}{*}{2003} & Malesice & 448 & - & \multirow{2}{*}{ Plzen̆ } & Nonplural & semiplural & 9 & 9 \\
\hline & Lhota & 419 & & & Semiplural & Plural & 7 & 7 \\
\hline & Zahořany & 223 & $\begin{array}{l}\text { until } 1991 \\
\text { Beroun }\end{array}$ & $\begin{array}{l}\text { Králüv } \\
\text { Dvír }\end{array}$ & Plural & Plural & 7 & 7 \\
\hline & Domoradice & 164 & $\begin{array}{c}\text { until } 1992 \\
\text { Vysoké Mýto }\end{array}$ & $\begin{array}{l}\text { Vysoké } \\
\text { Mýto }\end{array}$ & Nonplural & Nonplural & 6 & 6 \\
\hline
\end{tabular}

Source: Authors, based on data from Czech Statistical Office 


\section{Factors of mergers: problems, actors, processes}

\section{Jino, Kališstè, Stropčice ${ }^{8}$}

The municipalities were linked both by common historical experience of being part of Švihov and by cooperation in the Union of Municipalities, whose aim was to ensure gasification of the region (,Obce uvažuji o plynofikaci,“ 2001, p. 19) The situation prevailing in Jíno was described by mayor: "We do not have problems with money. The problem is that more and more responsibilities are transferred to small communities and great demands are placed on mayors" (Tichá, 2001, p. 2). Another reason was an ongoing public administration reform, which assigned Jíno, Kaliště and Stropčice under authority Přšštice. The municipalities, geographically located directly halfway between Přeštice and Klatovy, wanted to change this situation, partly because of better transport links and their ties to Klatovy generally. Moreover, it would have been impossible to merge with Švihov later, because of the borders of municipalities of the III ${ }^{\text {rd }}$ type. A quick merger, therefore, became the only solution. The last important factor was mutual geographic location, simply because only Kaliště had a common border with Švihov, which forced municipalities to quickly coordinate the process.

A merger process was then straightforward. The minutes of meeting of the municipal council of Jíno from Nov. 24, 2001 indicate that municipalities were not informed that their previous requests for inclusion under the municipality of the III ${ }^{\text {rd }}$ type Klatovy had been denied (Minutes of meeting No. 45). The mayors of the affected municipalities tried to reverse this decision by visiting Deputy Minister of the Interior, who, however, did not bring the desired solution and the municipality, therefore, decided to quickly connect to Švihov.

Therefore, the mayor and deputy mayor of Švihov were invited at the aforementioned meeting, and presented the opinion that the municipality agrees with the connection. Then, the councillors unanimously voted for the connection to Jan. 1, 2002. A similar process took place in the remaining two municipalities and two days later, the council of Švihov also approved the connection (Minutes of meeting No. 24 / 2011). Thus it is obvious that the mayors were the main actors of the process. The initiative came from the three small units and was coordinated in advance.

8 There is a territorial dependence in case of Jíno, Kaliště and Stropčice, that forced municipalities to cooperate in order to complete the merger successfully. Therefore, they will be examined together. 


\section{Prosatín}

The problem of Prosatín political system was primarily the age of candidates; their age was about 50 years on average. The council elected in 1998 was altered by only one councillor, the average age increased further; in addition, three of the five councillors in 2000 were more than 65 years old. (CSO) The case of Prosatín is affected by a lack of available information, which may be caused by a low number of inhabitants. Thus the minutes of meetings of the municipal council of Kuřimská Nová Ves remained the only source. According to these, it is clear that on November 30, 2001 the session was visited by Pavel Rouča, deputy mayor of Prosatín, who asked about the possible merger. He gave three main reasons: First, a small population and the consequent inadequacy of the budget for the fulfillment of the basic tasks, second, the death of several councillors, and the impossibility of further quorum. Related to the last reason, after the death of the councillors, the community cannot find candidates who would like to participate in the administration of the municipality (Minutes of the meeting of Kuřimská Nová Ves from Nov. 30, 2001). Despite the lack of additional information we conclude that the community in which it is necessary for more than $38 \%$ of population to participate in the candidate list and is also in the demographic trap, would rather pragmatically chose connections than maintaining independence in a hopeless situation.

\section{Hostokryje}

Hostokryje village experienced a scenario common to many small communities, which became independent in the early 90s. After the decline of enthusiasm of independent existence in the late 90 s, illustrated by a decreasing interest in participation in the political life of the community, Hostokryje realized that with the budget amounting to about $0.5 \mathrm{mil}$. CZK, it is very difficult to find the money for further development. One of the main problems was the missing water supply, which such a small unit cannot afford. Also, traffic connection was insufficient and without any public transportation, non-motorized citizens became virtually cut off from their surroundings. At the same time, Hostokryje faced an increasing average age of the population and local businesses leaving for larger cities. Mayor of Hostokryje Petr Kejla mentioned in a local newspaper: "The fact is, as such a small community, we cannot reach any subsidy from the state budget" (Mička, 2002, p. 16). The problems were even more evident when compared with Nouzov, another small village, which decided not to separate from Senomaty in 1991, as there was already a water supply and transport services were incomparably at a better level (Durčáková, 2008, p. 31).

The proposal to merge had come from Mayor of Senomaty Petr Valer, who 
was meeting his counterpart from Hostokryje at the meeting of representatives of micro-region Čistá and, therefore, knew their situation well. In 2001, he submitted a proposal for further consideration by both councils, which summarized the advantages and disadvantages of a merger. A definite advantage was an increase of the municipal budget by about 600 thousand CZK and the enlargement of the cadastral area, which would enable the further development (Durčáková, 2008 , p. 31). Merger then brought disadvantages mainly to Senomaty, which would have to ensure the accelerated development and repair the property of Hostokryje from its budget.

Both councils then turned to the citizens and asked for their opinion. In Senomaty a debate was held in the community centre, in which none of those present raised any objections. In Hostokryje a different approach was chosen, every citizen obtained a poll card with an accompanying letter to express their opinion (Kinkor, 2002). More than $72 \%$ of citizens were in favour of the merger (Durčáková, 2008, p. 32). The process was agreed at the meeting of both councils on Apr. 15. Unlike the other cases, a merger did not occur on Jan. 1, but on the date of the municipal elections - on 1 November, 2002 as was allowed by Municipalities Act until 2006.

\section{Zahorany}

Among the examined cases, only Zahořany can be described as a pluralistic system. The main motive of efforts of the council was to modernize the village. Since the mid-90s, the council tried to provide gas distribution network, water supply or canalization. In an election period after 1998, the council managed to reduce spending in the budget, thus the village in two years built up its financial reserves, which along with government subsidies largely enabled to meet some of the outlined objectives (Šimková, 2002a, p. 17). Although the municipality had financial reserves, it was clear that an annual budget of around 1.3 million does not enable any further investments as the canalization project counted on an investment of at least 17 mil. CZK (Beneš, 2014). The "municipal patriotism" also somewhat subsided and it was not clear whether the village would be able to build a list of candidates for the municipal elections in 2002 (Klima, 2002, p. 15). The idea that a merger may be a solution to the problem of modernization first appeared at a meeting of mayors of surrounding municipalities in the first half of 2002. The mayor of Zahořany mentioned there a problem with the financial demands of the investments, to which the mayor of Králův Dvůr responded that the situation would be solved through a merger. Zahořany council took this idea and according to its mayor, all councillors voted unanimously. Zahořany residents were passive regarding the idea and referendum was never formally 
debated (Beneš, 2014). Council of Králův Dvưr approved the connection on Aug. 7, 2002 (Minutes of meeting No. 4 / 2002). Based on the agreement, the unit was connected on Jan. 1, 2003 and in the following years, the investments into canalization were made, which opened the way for a new residential development. Zahorany is the only one from the explored municipalities, which began to significantly rehabilitate and expand after the merger (Beneš, 2014).

\section{Domoradice}

Domoradice resulted in the situation where the political life of the village stands on a single personality. The available information clearly indicates the fact that the political system stood on a person Václav Kučera, who was mayor since its independence. The moment he decided not to run for an office, resulted in a problem with the actual shortage of candidates (Koníček, Hubený, 2002, p.8). A required number of candidates was finally secured, but unfortunately with a small delay, one day after the deadline for submission. It is clear from the interview with the mayor that the merger was not considered at the moment, the mayor counted on by-election during the first half of 2003 (Koníček, Hubený 2002, p.8). The sources from before the merger also do not mention any significant problems, and the fact that the village was not part of an association of municipalities or other forms of municipal cooperation, indicates that the merger was a matter of collapsed political system. ${ }^{9}$

The idea of connecting the village appeared just before the election. The councillors approved the agreement on connection at a council meeting just three days before the local elections (Resolution of Domoradice from Oct. 29 2002). Council of Vysoké Mýto discussed the request on Nov. 13, 2002, and expressed an agreement with the connection by Jan. 1, 2003 (Minutes of the council meeting of Vysoké Mýto Nov. 13 2002). During the next thirty days, there was no proposal to hold a referendum and agreement was signed on Dec. 202002.

\section{Lhota}

The public administration reform became the main impetus for the merger. Lhota was recently assigned to a remote municipality of the III ${ }^{\text {rd }}$ type Stod. Also the issue of transport accessibility is related to the reform, as offices at Stod were not reachable enough by public transportation. Conversely, a connection to

9 Additional exploration of the period 2002-2005 showed that residents were promised certain improvements from the merger, that the municipality as a separate entity was unable to fund. There were complaints about the poor quality of roads and poorly maintained drainage system, which required reconstruction (Koníček, 2004, p. 8). 
Pilsen urban transport promised a radical improvement in traffic situation (Petr, 2002, p. 11). Like some other municipalities Lhota had not built water supply or canalization either, but neither councillors nor the citizens mentioned this as a serious problem in polls before merger (Petr, 2002, p. 11).

Lhota benefited from the talks about a possible connection that had already been launched in the municipality Chrást, whose representatives agreed on a merger with Pilsen in the first quarter of 2002. Lhota joined the process later, the first meetings took place during April and on May 21, the council expressed its agreement with the connection. On May 30, 2002, an extraordinary session of the council of Pilsen was held, where the request of municipalities and the state of the process in Lhota were presented. The poll among the citizens is explicitly mentioned in the Minutes of meeting (Minutes of the 39th Extraordinary Session of the Assembly of the City of Pilsen) where $72 \%$ of citizens favoured the merger. The next steps in the process were, however, affected by the amendment to Act on Municipalities. Merging units mistakenly believed that it is not possible to carry out the merger on the date of local elections, and requested legal confirmation. Additionally, Mayor of Pilsen in his campaign against the public administration reform warned that if they did not manage the merger by the municipal elections, it would be necessary to wait until the elections in 2006 (,Dalši obce chtěji patřit k Plzni,” 2002, p. 1). The legal opinion refuted both concerns; yet, the process was delayed so much that it was necessary to hold proper local elections. This brought the risk that the newly elected representatives would stop the process. The alternation did not occur and the process finished on Nov. 27, 2002 by signing the Agreement on connecting villages Lhota and Malesice (Agreement on connecting Lhota and Malesice).

\section{Malesice}

The merger in Malesice corresponds to a certain extent to the process described above. The first mention in official documents appeared in the minutes of the meeting of council from May 27, 2002, when one of the representatives out of the approved program proposed a merger with Pilsen and gave a speech summarizing the benefits that the merger would bring, namely the extension of public transport links and subsidies for roads improvement. ${ }^{10}$

In only one of the surveyed municipalities the mayor opposed the merger arguing that the process is too hasty and it would increase the tax burden on

10 The biggest problem was the inability to invest in modernization. Malesice was trying to solve the problem with lack of sewerage and wastewater treatment plants by a joint project of several neighbouring municipalities, but the project eventually failed because of its financial demands (Kozák, 2002, p. 9). 
citizens (Minutes of the 41st session of the council of Malesice). The citizens were informed only after Pilsen had approved the connection. Also a debate was held on July 5, where the citizens agreed on the merger (Kozák 2002, p. 17). The process could have been reversed with a replacement of political representation during the elections, but this never happened, and the new mayor promised to complete the process ("Chrást going to referendum..." 2002: 9). It is quite paradoxical that the municipality Chrást, which initiated the talks, eventually did not join as a local referendum on the issue did not fulfil the $50 \%$ quorum.

\section{Comparison of factors}

The following table summarizes the main factors of mergers as mentioned by the representatives of municipalities:

Among the reasons above, the economic factors in general have been the most frequently mentioned. Table 4 also shows that the highest frequency among the reasons is the inability to invest in the construction or completion of utilities (water, gas, sewer). This requirement is found in all the municipalities with more than 100 inhabitants. Representatives are aware of the fact that municipal budget is not sufficient for any investments of this magnitude, which makes further development impossible. It is also interesting that the smallest units never identified this impulse, even though neither of them was connected to sewerage or water supply. This can be attributed to the fact, that building such expensive projects with regard to annual budgets of municipalities up to 100 inhabitants, which usually is around 500 thousand CZK, is out of potential targets.

The second most common reason is insufficient frequency of public transport connections. With connecting to the larger community, in most cases, municipalities received an extension of the regional bus lines. The increasing administrative tasks appeared more frequently in the municipalities with fewer than 100 inhabitants, that have limited human resources. This issue is related to a non-plural political system which may collapse within one term.

Although there are aforementioned similarities in cases of Jíno, Kaliště, Stropčice and Prosatín, the underlying motive is different - in case of Prosatín it is an extremely small population. For the first three municipalities the surprising factor that entered the process was the public administration reform. All the surveyed municipalities belong to the category defined as the first type, i.e. those which perform only the basic delegated functions. The territorial aspect of the reform became a problem, as Kaliště, Jíno, Stropčice and Lhota should have been assigned to another municipality of the second type, which would not suit them from several reasons. This launched the considerations of the mergers. The 
territorial aspect of the public administration reform can thus be considered a single external stimulus.

Table 4: Comparison of main factors

\begin{tabular}{|c|c|c|c|c|c|c|c|}
\hline \multirow{2}{*}{ Municipality } & \multicolumn{2}{|c|}{$\begin{array}{c}\text { Administrative } \\
\text { factors }\end{array}$} & \multicolumn{4}{|c|}{ Economic factors } & \multirow{2}{*}{$\begin{array}{c}\begin{array}{c}\text { Socio - } \\
\text { demographic } \\
\text { factor }\end{array} \\
\\
\text { Population trap' } \\
\text { Lack of interest }\end{array}$} \\
\hline & $\begin{array}{c}\text { Increasin } \\
g \\
\text { administr } \\
\text { ative } \\
\text { tasks }\end{array}$ & $\begin{array}{c}\text { Territoria } \\
\text { l aspects } \\
\text { of public } \\
\text { administr } \\
\text { ation } \\
\text { reform }\end{array}$ & $\begin{array}{c}\text { Insufficie } \\
\text { nt } \\
\text { transport } \\
\text { connectio } \\
\text { n }\end{array}$ & $\begin{array}{l}\text { Conditio } \\
\mathrm{n} \text { of roads }\end{array}$ & $\begin{array}{l}\text { Investme } \\
\text { nts into } \\
\text { utilities }\end{array}$ & $\begin{array}{l}\text { Insufficie } \\
\text { nt budget }\end{array}$ & \\
\hline $\begin{array}{c}\text { Jíno, Kaliště, } \\
\text { Stropčice }\end{array}$ & $\checkmark$ & $\checkmark$ & $\checkmark$ & & & & \\
\hline Prosatín & $\checkmark$ & & & & & $\sqrt{ }$ & $\checkmark$ \\
\hline Hostokryje & & & $\checkmark$ & & $\checkmark$ & $\checkmark$ & \\
\hline Zahor̆any & & & & $\sqrt{ }$ & $\checkmark$ & $\sqrt{ }$ & \\
\hline Domoradice & & & & $\checkmark$ & $\sqrt{ }$ & & $\sqrt{ }$ \\
\hline Lhota & & $\checkmark$ & $\checkmark$ & & $\checkmark$ & & \\
\hline Malesice & & & $\checkmark$ & $\checkmark$ & $\checkmark$ & & \\
\hline Total & 2 & 2 & 4 & 3 & 5 & 3 & 2 \\
\hline
\end{tabular}

Source: authors

Municipalities can also be divided from the perspective of an initiator of the idea of merger. As shown in Table 5, municipalities may be visibly divided into two groups. In the first group, there are smaller communities - Jíno, Kaliště, Stropčice, Prosatín and Domoradice. Neither one of them showed the signs 
of a plural political system during the period under review and they initiated the merger in all cases. The second group then includes all the remaining municipalities, which are, except for Hostokryje, larger in terms of population (over 200 people), thus Lhota, Malesice and Zahořany. These municipalities are connected by the fact that in at least one election, the system left the non-plural position and at least $\mathrm{S}^{11}+1$ candidates ran for the office, while the impulse to merge came from a target municipality.

Table 5: Initiators of the merger

\begin{tabular}{|l|l|l|l|l|l|l|l|}
\hline & $\begin{array}{l}\text { Jíno, } \\
\text { Kaliště, } \\
\text { Strop- } \\
\text { ćice }\end{array}$ & Prosatín & $\begin{array}{l}\text { Hosto- } \\
\text { kryje }\end{array}$ & $\begin{array}{l}\text { Zahořa- } \\
\text { ny }\end{array}$ & $\begin{array}{l}\text { Domo- } \\
\text { radice }\end{array}$ & Lhota & Malesice \\
\hline $\begin{array}{l}\text { Initiator } \\
\text { of the } \\
\text { merger }\end{array}$ & $\begin{array}{l}\text { Di- } \\
\text { sappea- } \\
\text { ring } \\
\text { units } \\
\text { sappea- } \\
\text { ring unit }\end{array}$ & $\begin{array}{l}\text { Di- } \\
\text { tent unit }\end{array}$ & $\begin{array}{l}\text { Persis- } \\
\text { tent unit }\end{array}$ & $\begin{array}{l}\text { Di- } \\
\text { sappea- } \\
\text { ring unit }\end{array}$ & $\begin{array}{l}\text { Persis- } \\
\text { tent unit } \\
+ \text { inspi- } \\
\text { ration } \\
\text { fom } \\
\text { another } \\
\text { munici- } \\
\text { pality }\end{array}$ & $\begin{array}{l}\text { Persis- } \\
\text { tent unit } \\
\text { inspi- } \\
\text { ration } \\
\text { from } \\
\text { another } \\
\text { munici- } \\
\text { pality }\end{array}$ \\
\hline
\end{tabular}

Source: authors

In several cases, coincidence also played a role - as a former mayor of Zahořany spoke openly in an interview, the idea for the merger resulted from a random discussion with other mayors and the council itself never considered a similar possibility. Similarly, it was also the case of Domoradice and Vysoké Mýto, where the merge was caused by a trivial delay in drawing up the lists of candidates.

\section{Conclusions}

As it is evident from the previous text that the cases of voluntary mergers in 2002 and 2003 cannot be connected based on one or more common factors, as there are too many different motives. Also, the hypothesis that the accumulation of mergers was caused by changes in an allocation of shared taxes was not proved, because the reform was not mentioned as a reason in any of the available resources. This interim conclusion, together with the findings from the contextual part, therefore, supports the hypothesis that for the successful voluntary consolidation $11 \mathrm{~S}=$ seats 
on a greater scale, the methodological and financial support from the centre is necessary.

Comparing all the aspects above, it seems particularly interesting, that in neither of the cases the merger was under consideration as a solution of longterm problems with budget or investments, but it was discussed either on the basis of inspiration from other municipalities or at the time of a direct threat to the functioning of municipality.

The research has also shown that the mayor was a central actor in nearly all cases, which can be attributed to the fact that in small villages the mayor is usually a single person who cares about the running of community and participates in the meetings with mayors of surrounding municipalities, where problems of the units are discussed. However, during the research, it was revealed that the actors often fail to obtain all the relevant information on time. The clearest example of a similar hesitation is the case of merging Lhota and Malesice, which had to be postponed because of the Pilsen Mayor's statement that if the merger misses the date of the local elections in 2002 , it will be necessary to wait until the elections in 2006.

If the Czech Republic decides to go the way of support for voluntary consolidation of a municipal structure, a set of recommendations can then be created by the basic facts detected, which could help the process to be successfully applied. The first step should be taking the systemic and administrative capacities of Czech municipalities into account and focus on simplicity and clarity of the process. There should also be an introduction of financial support, again with an emphasis on clear and understandable rules of the subsidy. Last but not least, the administrative assistance should be provided as close as possible to the target communities. One example of secure administrative support is availability of information by several independent channels and the existence of simple manuals that are able to lead the actors through the entire process. It is then necessary for existing tools to highlight the positive impact of the fact that merging municipalities do not need a referendum on the issue. The influence on the outcome of the merger can be seen on the example of an aforementioned village Chrást or in the Slovak Republic.

\section{References}

BALDERSHEIM, H. - ILLNER, M. - WOLLMANN, H. (eds.): Local Democracy in PostCommunist Europe. Opladen: Leske + Budrich, 2003. 340 s. ISBN 3-8100-3192-5.

BALDERSHEIM, H. - ROSE, L. E.: Territorial choice: the politics of boundaries 
and borders. New York: Palgrave Macmillan, 2010, 283 s. ISBN 978-0230233-331.

BALÍK, S.: Komunální politika: obce, aktéři a cíle místní politiky. Vyd. 1. Praha: Grada, 2009. 250 s. ISBN 978-802-4729-084.

BLESSE, S. - BASKARAN, T.: Do Municipal Mergers Reduce Costs? Evidence from a German Federal State. [online] [cit. 12. 5. 2014] Dostupné z: http:// ssrn.com/abstract $=2365979$

CDLR (The European Committee on Local and Regional Democracy), Reports prepared in the famework of the Steering Committee on Local and Regional Authorities. The size of municipalities, efficiency and citizen participation. Strasbourg: Council of Europe Press, 1995. ISBN 978-928-7126-580

ČMEJREK, J. - BUBENÍČEK, V. - ČOPÍK, J.: Demokracie v lokálním politickém prostoru. Specifika politického života v obcich ČR. Praha: Grada, 2010. 224s. ISBN 978-80-247-3061-5.

DAFFLON, B.: Voluntary amalgamation of local governments: the Swiss debate in the European context. International Center for Public Policy Working Paper Series, at AYSPS, GSU paper1204, International Center for Public Policy, Andrew Young School of Policy Studies, Georgia State University, 2012. [cit. 16.11.2014] Dostupné z: http://unifr.ch/finpub/assets/files/ RecherchesPublications/Bernard\%20 Dafflon/110_chapter_8_voluntaryamalgamation-of-local-governments-the-swiss-debate-in-the-europeancontext.pdf

DURČÁKOVÁ, D.: Osobni a územni aspekt místni samosprávy v České republice. Brno. Dostupné z: http://is.muni.cz/th/186095/pravf_b/.Bakalářská práce. Právnická fakulta Masarykovy univerzity, 2008. Vedoucí práce JUDr. Stanislav Kadečka, Ph.D.

ILLNER, M.: The Voluntary Union of Municipalites: Bottom-up Territorial Consolidation in the Czech Republic? In SWIANEWICZ, P. (ed): Territorial consolidation reforms in Europe. Budapest: Open Society Institute, 2010. 219-236. ISBN 978-963-9719-16-3. s. 219 - 236.

ILLNER, M.: Velikost obcí, efektivita jejich správy a lokální demokracie. In Vajdová, Z. - Čermák, D. - Illner, M.(eds.): Autonomie a spolupráce: důsledky ustavení obecního zřízení v roce 1990. Praha: Sociologický ústav Akademie věd ČR, 2006. s. 15-26. ISBN 80-7330-086-9.

HORNEK, J.: Politické dopady zadlužování malých obcí v ČR. Diplomová práce. Praha: Fakulta sociálních věd Univerzity Karlovy. Vedoucí práce PhDr. Petr Jüptner, Ph.D. 384 s.

KEATING, M.: Size, Efficiency and Democracy: Consolidation, Fragmentation and Public Choice." In: Judge, D.; Stoker, G.; Wollmann, H. (eds.) Theories 
of Urban Politics, London: Sage, 1995.

KLING, J. - NIZNANSKY, V. - PILAT, J.: Separate Existences Above All Else:

Local Self-Governments and Service Delivery in Slovakia. In SWIANEWICZ,

P. (ed.): Consolidation or Fragmentation? The Size of Local Governments in Central and Eastern Europe. Budapest: Open Society Institute, s. 101-166. ISBN 963-9419-45-1.

LAGO-PEÑAS, S. - MARTINEZ-VAZQUEZ, J.: The challenge of local government size: theoretical perspectives, international experience and policy reform. Studies in fiscal federalism and state-local finance, 2013. 291 s. ISBN 17-825-4429-1.

OECD.: OECD Regional Outlook 2014: Regions and Cities: Where Policies and People Meet, OECD Publishing, 2014. DOI: 10.1787/9789264201415-en

RŮŽKOVÁ, J.: Historický lexikon obcí České Republiky 1869-2005. 1. vyd. Praha: Český Statistický Úřad, 2006. ISBN 80-250-1310-3.

RYŠAVÝ, D. - BERNARD, J.: Size and Local Democracy: the Case of Czech Municipal Representatives. Local Government Studies, vol. 39, issue 6, 2013, s. 833-852.

SAARIMAA, T. - TUKIAINEN, J.: Common Pool Problems in Voluntary Municipal Mergers. Government Institute for Economic Research Working Papers, 2013, s. 53.

STEINER, R.: The causes, spread and effects of intermunicipal cooperation and municipal mergers in Switzerland. Public Management Review. 2003, roč. 5, č. 4 , s. 554.

SWIANIEWICZ, P.: If territorial fragmentation is a problem, is amalgamation a solution? An east European perspective.Local Government Studies, vol. 36, č. 2, 2010, s. 183-203.

SWIANIEWICZ, P.: Is There a Third Road Between Small yet Ineffective and Big yet Less Democratic? Comparative Conclusions and Lessons Learned. In SWIANEWICZ, P. (ed.): Consolidation or Fragmentation? The Size of Local Governments in Central and Eastern Europe. Budapest: Open Society Institute, 2002a, s. 293-326. ISBN 963-9419-45-1

SWIANIEWICZ, P.: Territorial consolidation reforms in Europe. Budapest, Hungary: Local Government and Public Service Reform Initiative, Open Society Institute, 2010. ISBN 96-397-1916-1.

VAJDOVÁ, Z. - ČERMÁK, D. - ILLNER, M.: Autonomie a spolupráce: di̊sledky ustaveni obecního zř́zení v roce 1990. Sociologické studie / Sociological Studies 06:2. Praha: Sociologický ústav AV ČR, 2006. 108 s. ISBN 80-7330-086-9.

WOLLMANN, H.: Local government reforms in (seven) European countries: 
between convergent and divergent, conflicting and complementary developments, in: Local Government Studies, vol. 38, no. 1, 2012, s. 41-70 (ISSN 0300 3930)

\section{Documents, legislation and primary sources}

BENEŠ, F.: Polostrukturovaný rozhovor, Zahořany. 9. 5. 2014

ČESKÁ REPUBLIKA: Parlament České republiky, 2000 Sněmovní tisk 435/0. [citováno 10. 10. 2014]. Dostupné z: http://www.psp.cz/sqw/text/tiskt. sqw $? \mathrm{O}=3 \& \mathrm{CT}=435 \& \mathrm{CT} 1=0$

ČESKÁ REPUBLIKA: Ústava České republiky. Ústavní zákon č. 1/1993 Sb. ve znění ústavního zákona č.347/1997 Sb., 300/2000 Sb., 448/2001 Sb., 395/2001 Sb., 515/2002 Sb. a 319/2009 Sb.

ČESKÁ REPUBLIKA: Zákon č. 22 Sb. ze dne 11. května 2003 o místním referendu a změně některých předpisů. In Sbírka zákonů České republiky. 2004, částka 7, s. 366-379.

ČESKÁ REPUBLIKA: Zákon č. 128 ze dne 12. dubna 2000 o obcích (obecním zř́zení). In Sbírka zákonů České republiky. 2000, částka 38, s. 1737-1764.

ČESKÁ REPUBLIKA: Zákon 152/1994 Sb: Zákon o volbách do zastupitelstev v obcích a o změně a doplnění některých dalších zákonů. In: Sbírka zákonů České republiky. 1994, částka 48. s. 1577-1593

ČESKÁ REPUBLIKA: Zákon č. 243/2000 Sb. Zákon o rozpočtovém určení výnosu některých daní územním samosprávným celkům a některým státním fondům (zákon o rozpočtovém určení daní) In Sbírka zákonů České republiky. 2000, částka 73, s. 3513-3516.

ČESKÁ REPUBLIKA: Zákon č. 367/1990 Sb. Zákon o obecním zřízení In Sbírka zákonů České republiky. 1990, částka 59, s. 1261-1271.

DOMORADICE: Usnesení jednání zastupitelstva obce Domoradice ze dne 29. 10. 2002, které schvaluje dohodu o připojení obce Domoradice k městu Vysoké Mýto. Domoradice. Dostupné v archivu města Vysoké Mýto.

JíNO: Zápis schůze zastupitelstva č. 45 obce Jíno, konaného dne 24. 11. 2001. Jíno. Dostupné v archivu obce Švihov.

KUŘIMSKÁ NOVÁ VES: Zápis z jednání zastupitelstva obce Kuřimská Nová Ves ze dne 30. 11. 2001. Kuřrimská Nová Ves. Dostupné v archivu obce Kuřimská Nová Ves.

KRÁLU゚V DVU゚R: Zápis jednání zastupitelstva č.4/2002 města Králův dvůr. Dostupné v archivu města Králův Dvůr.

MALESICE: Zápis ze 41. zasedání Zastupitelstva obce Malesice ze dne 27. 5. 2002, Malesice. Dostupné v archivu městského obvodu Plzeň IX. 
PLZEŇ: Zápis z 39. mimořádného zasedání Zastupitelstva města Plzně. 30.5 2002, Plzeň. Dostupné v archivu obce Plzeň.

PLZEŇ: Dohoda o připojení obcí Lhota a Malesice, Plzeň. Dostupné v archivu obce Plzen̆.

ŠVIHOV: Zápis 24/2001 ze zasedání zastupitelstva města Švihov konaného dne 26. 11. 2001. Švihov. Dostupné v archivu obce Švihov.

\section{Periodicals, media, press releases}

Chrást chystá referendum, jestli bude součástí Plzně. Deník Právo: Plzeňský kraj, 15. 11. 2002

Dalši obce chtěji patřit k Plzni. Mladá fronta Dnes: kraj Plzeňský, 29. 5. 2002.

Jino, Kaliště i Stropčice jsou již součástí Švihova. Klatovský deník, 5. 1. 2002.

KINKOR, O.: Hostokryje se po dvanácti letech vrací $k$ Senomatům. Mladá fronta Dnes: Rakovnicko, 25. 5. 2002.

KLÍMA, M.: Zahořanská ztráta prrinese zisk. Berounský deník, 11. 4. 2002.

KONÍČEK, J. - HUBENÝ, J.: Dvě obce budou volit napřesrok. Orlické noviny, 27. 9. 2002.

KONÍČEK, J.: Na Domoradice se nezapomíná. Orlické noviny, 17. 7. 2003.

KONÍČEK, J.: První je na řadě oprava silnic. Orlické noviny, 2. 2. 2004.

KOZÁK, V.: VChrástu i Malesicích ještě lidé mohou ovlivnit slučování. Plzeňský deník, 23. 7. 2002 (a).

KOZÁK, V.: Malesice potřebují cesty a kanalizaci. Plzeňský deník, 29. 4. 2003. MIČKA, I.: Senomaty a Hostokryje společně. Rakovnický deník, 28. 11. 2002. Obce uvažují o plynofikaci. Klatovský deník, 30.7.2001.

PETR, M.: Malesice a Lhota se připojily, Velká Plzeñ je skutečností. Plzeňský deník, 29. 11. 2002.

Plzeňsko zahájilo nový rok ojedinělou integraci obci. Hospodářské noviny: Plzeňsko, 24. 2. 2003.

ŠIMKOVÁ, R.: Kolem domů začalo být rušno. Berounský deník, 9. 8. 2002 (a) . ŠIMKOVÁ, R.: Zahořany musí odhalit tvářr. Berounský deník, 5. 8. 2002 (b). TICHÁ, E.: Obce chtěji ke Švihovu. Mladá fronta Dnes, 30. 11. 2001.

\section{Internet sources}

Eurostat, 2014. Total local government expenditure, (tabulka tec0002) [online]. Luxembourg: Eurostat. [cit. 18. 12. 2014], Dostupné z: http://ec.europa.eu/ eurostat $/$ tgm/refreshTableAction.do?tab=table\&plugin $=1 \&$ pcode $=$ tec00023 \&language $=\mathrm{en}$

Eurostat, 2009. Local Administrative Units (LAU 2) [online]. Luxembourg: 
Eurostat. [cit. 18. 12. 2014], Dostupné z: http://ec.europa.eu/eurostat/c/portal/ layout?p_1_id=345247\&p_v_1_s_g_id=0

German Statistical Offices of the Federation and the Länder, 2014. Tabulka:

National accounts - Gross domestic product [online] Wiesbaden: Federal

Statistical Office [cit. 18. 12. 2014]. Dostupné z: http://www.statistik-portal. de/Statistik-Portal/en/en_jb27_jahrtab65.asp

Územní změny, počty obyvatel, narození, zemřelí, stěhování (1971-2013), 2013.

[online]. Praha: ČSÚ, 2013. [cit. 12. 12. 2014], Dostupné z http://www.czso. cz/cz/obce_d/pohyb/cz0322.xlsx

Volby do zastupitelstev obci 1994: Výsledky hlasování - výběr obce dle názvu [online]. Praha: ČSÚ, 1994. [cit. 12. 12. 2014], Dostupné z http://www.volby. $\mathrm{cz} / \mathrm{pls} / \mathrm{kv} 1994 / \mathrm{kv} 11$ ? xjazyk $=\mathrm{CZ} \& \mathrm{xid}=1$

Volby do zastupitelstev obcí. 1998: Výsledky hlasování - výběr obce dle názvu [online]. Praha: ČSÚ, 1998. [cit. 12. 12. 2014], Dostupné z http://www.volby. $\mathrm{cz} / \mathrm{pls} / \mathrm{kv} 1998 / \mathrm{kv} 11$ ? xjazyk $=\mathrm{CZ} \& \mathrm{xid}=0$

Volby do zastupitelstev obcí. 2002: Výsledky hlasování - výběr obce dle názvu [online]. Praha: ČSÚ, 2002. [cit. 12. 12. 2014], Dostupné z http://www.volby. $\mathrm{cz} / \mathrm{pls} / \mathrm{kv} 2002 / \mathrm{kv} 11$ ? xjazyk $=\mathrm{CZ} \& \mathrm{xid}=0$

Volby do zastupitelstev obcí. 2006: Výsledky hlasování - výběr obce dle názvu [online]. Praha: ČSÚ, 2006. [cit. 12. 12. 2014], Dostupné z http://www.volby. $\mathrm{cz} / \mathrm{pls} / \mathrm{kv} 2006 / \mathrm{kv} 11$ ?xjazyk $=\mathrm{CZ} \& \mathrm{xid}=0$

Volby do zastupitelstev obcí. 2010: Výsledky hlasování - výběr obce dle názvu [online]. Praha: ČSÚ, 2010. [cit. 12. 12. 2014], Dostupné z http://www.volby. $\mathrm{cz} / \mathrm{pls} / \mathrm{kv2010} / \mathrm{kv11}$ ?xjazyk $=\mathrm{CZ \& xid=1}$ 